VERSLAS: TEORIJA IR PRAKTIKA / BUSINESS: THEORY AND PRACTICE

ISSN 1648-0627 / elSSN 1822-4202

http://www.btp.vgtu.lt

2015 16(1): 75-83

doi:10.3846/btp.2015.462

\title{
SOCIAL NETWORKS AND THEIR IMPORTANCE IN JOB SEARCHING OF COLLEGE STUDENTS
}

\author{
Marek POTKÁNY ${ }^{1}$, Alexandra HAJDUKOVÁ ${ }^{2}$ \\ Department of Enterprise Management, Faculty of Wood Sciences and Technology, Technical University in Zvolen, \\ T. G. Masaryka 24, 96053 Zvolen, Slovakia \\ E-mails: ${ }^{1}$ potkany@tuzvo.sk (corresponding author); 2 alexandra.hajdukova@gmail.com
}

Received 27 March 2014; accepted 26 January 2015

\begin{abstract}
At present, in every sphere of human activity, using modern ICT is considered as a matter of course. Several human resources management institutions are aware of the potential of social networks in estabilishing and building relationships with their target groups. It is a trend to create job portals in social networks. These are currently an integrated part of communication with target audience and therefore also an objects of attention and reflexions. It is also the topic of this paper. The goal of this research is to determine the level of use of social networks by college students in Slovakia. Part of the research is also to discover the effect of social networks on job searching of a selected sample of students. The research was conducted on a sample of 407 slovak students. A questioning method in form of an online questionnaire was used. The obtained results were processed using methods of descriptive and test statistics. We studied the significance of gender on the frequency of using the internet to search for job opportunities via social networks, as well as the ability to apprehend the importance of personal presentation on social networks. The statistical testing did not prove any significant difference between men and women in the question of frequency of using internet to search for job opportunities, nor in the ability to apprehend the importance of personal presentation on social networks. A statistically significant difference in gender was proven only in case of using social networks in job searching. Women tend to use social networks to find jobs more often than men. These statements are proved by the results of tests of significance of mean changes at the $5 \%$ significance level, which means that they are valid with $95 \%$ probability.
\end{abstract}

Keywords: social networks, job search, recruiting, university students.

JEL Classification: A14, D83, J64, J70.

\section{Introduction}

Road, public, and communication networks have been a part of development and basic elements of human civilisation within living memory. At the present time the Internet plays an essential role in everyday life and it has serious impact on social interaction among people. Social networks are mostly used for fast changing and sharing of various types of information among people and that is why they develop enormously. Popularity and significance of utilization of social networks have not reached the top yet. We can see the potential of social networks mainly in the area of formation and utilization of personal presentation of their users and consequent possibility of looking for an attractive job. Mainly American companies use social networks very often as one of the best quality sources for hiring appropriate candidates for free career positions. Opportunity for utilization of social networks to gain full job market value in Slovakia with their own offer and demand is closely connected with the purpose and frequency of using these sites by the Slovaks. The aim of the paper is to present current state of utilization and the effect of social networks on job search of selected test sample of Slovak university students.

\section{Importance of social networks}

The origin of the theory of social networks can be dated back to the early 1930s within three different scientific

Copyright (C) 2015 The Authors. Published by VGTU Press.

This is an open-access article distributed under the terms of the Creative Commons Attribution-NonCommercial 4.0 (CC BY-NC 4.0) license, which permits unrestricted use, distribution, and reproduction in any medium, provided the original author and source are credited. The material cannot be used for commercial purposes.

To link to this article: http://dx.doi.org/10.3846/btp.2015.462 
branches - psychology, anthropology and mathematics. In this early age the first work made a big contribution; his so-called "sociograms" aimed at graphical plotting of relationship between individuals by means of lines connecting points. Due to them it was possible to identify leaders, separate members, interaction and reciprocity within friendships in specific groups (Mayer 2012). Another author revised the concept significantly. Barnes focused on community relations which went beyond limits of traditional groups (family, society, etc.) whereby new research method - analysis of social networks was developed gradually (Cook, Whitmeyer 1992). Authors like Ronald Burt, Mark Granovetter, Stanley Milgram, Steven Strogatz or Ducan Watts are regarded as classical theorists of social networks. At the time of their living the term of social networks was understood to be one of two approaches how to perceive social structure. In general this concept is more abstract (Ioanides, Loury 2004). We can differentiate two basic structure concepts. In the more common of them the structure is explained as a scheme of particular relations between persons involved. In the other one the structure is perceived as universal, maybe multidimensional accidentally variance (Cook, Whitmeyer 1992). The difference is in perception of relations and their origin.

Definition of social network varies from the point of view of different authors. It is possible to define it as an interconnected group of people who affect each other. According to James Clyde Mitchel social network is understood as a "specific relation in defined group of people. The nature of relations in social networks can be used for interpretation of these relations" (Clyde 1969). Social network is a web service allowing an individual to create public or semi-public profile within limited system interconnected with other users who they share content with, and it allows them to look through and list the connections with other users within this system (Boyd 2008). One of the possible approaches to social networks is as follows - "Social network is a structure composed of a set of persons involved, some members are interconnected by a set of one or more relations" (Knoke, Yang 2008). The Dictionary of Sociology defines social network as a "set of social subjects interconnected with nominal relations. Subjects are nodal points of network; relations are presented by points that are aligned" (Jandourek 2007).

Social networking websites are virtual communities which allow people to connect and interact with each other on a particular subject or to just "hang out" together online (Murray, Waller 2007). Membership of online social networks has recently exploded at an exponential rate. For example, the market share of the top 20 social networking websites grew by 11.5 percent from January 2007 to February 2007, social network website activity accounted for 6.5 percent of all Internet traffic in February 2007 (Hitwise 2007). Indeed, the popularity of social networking sites is highly demonstrable by the number of people using them. It is also measured by the amount of interactions per user taking place on the network. Since social interactions and connection is the objective of online social networks, it is more appropriate to consider the use of online social networks as collective social action (Cheung, Lee 2010; Ordóñez de Pablos 2002; Rodriguez Pérez, Ordóñez de Pablos 2003; Zhao, Ordóñez de Pablos 2010a, 2010b; Stachová, Stacho 2010).

As the term social network is closely associated with the term to socialise, which means to form and to improve human personality (especially their thinking, feeling and behaviour) and to create and to master human relations, it becomes significant gradually at the time of new technologies. According to Short, Williams, and Christie (1976), social presence is "the degree of salience of the other person in the interaction and the consequent salience of interpersonal relationships" (Short et al. 1976). The presence of others in a virtual environment is important because it implies direct or indirect human contact Gefen, Straub (2004) and Vetráková et al. (2011). Individuals participating in a virtual social networking site can perform communication in a style that is similar to face-to-face communication. Social influence has been widely used to explain group and collective behaviour (Bagozzi, Lee 2002).

Social networks have developed intensively to the form of these days. Many types of worldwide social networks are available today, e.g. Twitter, Facebook, You tube, LinkedIn, Myspace, Google+ and Xing. We can see the potential of social networks mainly in the area of formation and utilization of personal presentation of their users and consequent possibility of finding an attractive job.

\subsection{Social networks and job search}

In the 1990s most people job search reached for the advertisements, nowadays the Internet is most commonly used media when job search (Sedláček 2012). In the 1990s the HR departments were only formed in most companies and they have become significant gradually. It was not difficult to recruit a candidate for free job position after publishing print advertisement in daily press. First web portals and servers focused on job offers and demands appeared at the turn of millennium. In the previous five years companies have had to be creative enough when recruiting new employees. A traditional advertisement is often not adequate for specialized positions, where the best employees are needed and the process of head hunting is carried out. Head-hunters address the specialists directly and hunt them via social networks.

Why social networks? Because they connect people with same interests, professions and individual values. It was always true that personal references are very important when hiring the right candidate. By means of social 
networks it is easier to get the references. It is possible to distinguish a "good" from a "bad" candidate by means of social networking business card. And it is just what human resources require nowadays - having the candidate's background with detailed references. Some warranty, that the candidate polled meets the demands, is generated and it is possible to concentrate on other characteristic features of the candidate.

How about job offers and hiring potential employees from the point of view of personalists and specialized recruitment agencies focused on recruitment? Most of them have obviously their own web portal. The companies have, more often, their own social networking site profiles. Specialized recruitment agencies found out that communication via web or via social networks is, for specific professions or groups of people, much more effective than common advertisements and not only those in press but also on the Internet. The main cause is that young people read daily press less and they spend more time on social networking sites. Another advantage is that information spreads very fast and affects many people involved in very short time (Sedláček 2012).

\subsection{Utilization of social networks for recruitment in the USA}

The company Jobvite, Inc. has regularly carried out a research focused on the recruitment via social networks. The survey in the year 2011 was carried out with approximately 800 respondents from the area of HR and recruitment. From 2007 to 2011 the time spent on social networking sites doubled. When 4 years ago the Internet users spent on average 1 from 12 minutes online; in 2011 it was already each $6^{\text {th }}$ minute spent online (Jobvite 2011).

The result of the research of the company Jobvite was that $89 \%$ of American companies polled use and plan to use social networks to support hiring new employees; $80.2 \%$ of companies use social networks and media to support hiring new employees already today. This figure has grown significantly, more than $12 \%$, since the year 2009 . According to this research American companies look for candidates for new jobs most often via the site LinkedIn.com (Fig. 1).

To confirm that recruitment via social networks works we know the fact that $63.6 \%$ of American companies polled employed successfully a candidate from social networks. Firms can hire people for their needs from different sources. Quality of candidates from specific sources is presented in Figure 2 (10 means the best quality). As we can see from the previous graph the best employees come from references, direct sources and social networks. A candidate searched via social network is even in better quality than the candidate improving their career and climbing the corporate ladder or is hired through university recruiting system.

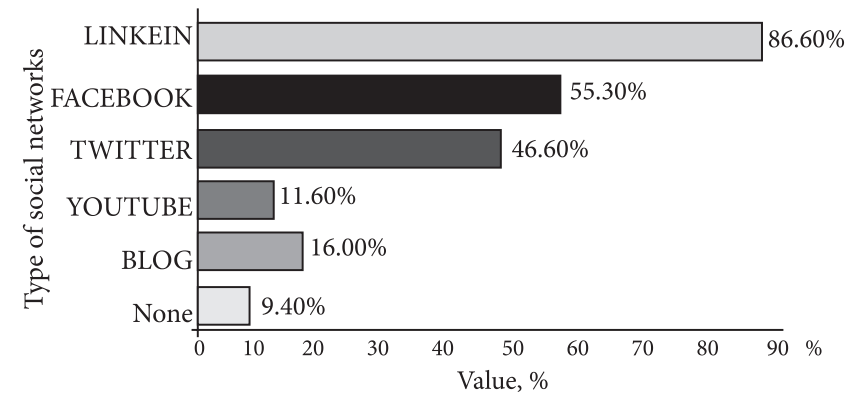

Fig. 1. Utilization of social networks for recruitment in the U.S.A in the year 2011 (source: Jobvite 2011)

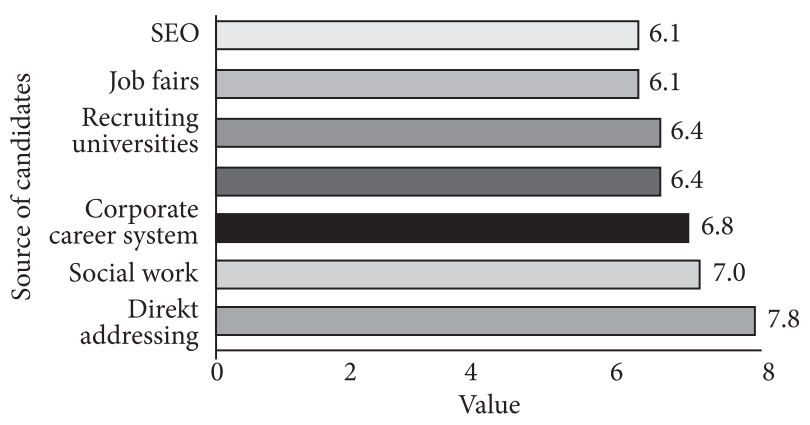

Fig. 2. Quality rating of candidates of different sources (source: Jobvite 2011)

\section{Data and methodology}

The survey of the current state of utilization and of the effect of social networks on job search of selected test sample of Slovak university students took place from December 2011 to May 2012. Relevant data for carrying out the objective research were determined through selective determination, it means through items of selective set. Selective set consists of 407 respondents, students and graduates of selected Slovak Universities (Technical University in Zvolen, Slovak University of Technology in Bratislava, Constantine the Philosopher University in Nitra, Alexander Dubček University of Trenčin).

The survey was conducted through specific on-line questionnaire accessible on this web address: https://docs. google.com/spreadsheet/viewform?formkey=dHdpS0t 1 OHJ1VTFrNjEzaDE5T0lnNlE6MQ. The questionnaire consisted of 16 questions with options for answer given in advance. 3 types of answers were offered in the questionnaire. Respondents were allowed to choose easily from answers (to tick off only 1 possible answer) in most of questions in the questionnaire (13 questions). In one question respondent had the possibility to tick off more than one answer. In two questions in the questionnaire respondent was offered dichotomous response, yes-no answer. The first part of the questionnaire examined socio-demographic characteristics of respondents; it means data about age, gender, completed education of respondents. Information describing current 
state of social networks utilization (type, purpose, frequency) as well as experience and possibilities associated with job search on the job market via the Internet and social networks was gained in the second part of the questionnaire. Demographic structure corresponds with accomplishing the aim in reality. Large group of respondents were 23-30 years old and more than $60 \%$ of them were women.

To assess the questionnaire each item was assessed separately. Questions were assessed globally, regardless of age, gender and completed education. Because of the article size there are presented only results of selected questions from the questionnaire. Frequency of answers for each of offered choice was assessed by particular questions. Frequency was stated by means of relative expression (in \%). Acceptance analysis for new information technology often uses gender difference (Hitka et al. 2013; Hitka, Balážová 2013) among all personality features (Sanchez-Franco 2006), mainly men and women have different views for measuring value and benefit (Venkatesh, Morris 2000).

By these reasons were selected four selected questions from the questionnaire were assessed extra according to gender. The purpose of the assessment of these questions was to verify hypotheses $\mathrm{H} 1, \mathrm{H} 2, \mathrm{H} 3$.

H1: We suppose that the gender difference of respondents does not have statistically significant effect on the Internet utilization (except social networks) for job search by Slovak university students.

H2: We suppose that the gender difference of respondents does not have statistically significant effect on social networks utilization for finding new business contacts and job opportunities by Slovak university students.

H3: We suppose that the gender difference of respondents does not have statistically significant effect on perceiving of the importance of personal presentation on social networks from the point of view of job search neither nowadays nor in the future.

Following questions were assessed:

1) Have you ever used the Internet (except social networking sites) for job search?

2) Do I use social networks mainly for finding new business contacts and job opportunities?

3) Is personal presentation on social networking sites from the point of view of job search important for you?

4) Do you emphasise personal presentation on social networking sites for job search in the future?

When working out the questionnaire items particular answers were transformed to points. Questionnaire items were scored as follows: Question 1) 1 point for each answer (no, there are many other relevant things important when job search), 2 points for the answer (yes, but it does not have important role), 3 points for the answer (yes, it is very important). Question 2) 1 point for the answer (no, never), 2 points for the answer (yes, once), 3 points for the answer (yes, I look for a job this way regularly). Question 3) 1 point for each answer (by no means), 2 points for the answer (exceptionally), 3 points for the answer (on average), 4 points for the answer (significantly). Question 4) I point for each answer (irrelevant), 2 points for the answer (less significant), 3 points for the answer (medium significance), 4 points for the answer (high significance) and 5 points for the answer (extreme significance). Arithmetic means and standard deviations of answers to particular questions were counted after transformation of items to points by means of the programme STATISTICA 7. With respect to the character of gained data it was acceded, in addition to simple comparison of values of descriptive characteristics, to test equality of arithmetic means and standard deviations of answers to particular questions of compared sets (male and female). Within tests the main task was to verify statistical significance of differences of arithmetic means and standard deviations of particular answers to monitored questions so that it was eliminated on the selected significance level $\alpha$ (0.05) that determined differences of descriptive characteristics were not caused only by a fault of representation. To test the equality of arithmetic means T-test in the programme STATISTICA 7 was used. This programme supposed the independence of choices and unequal dispersion of determined data. Null hypothesis and alternative hypothesis were stated for particular questions. At the end of the test $t$ was compared to $t_{\alpha / 2 ; f}$ in case when $t \leq t_{\alpha / 2 ; f}, H_{0}$ was accepted and difference was not considered significant, on the contrary when $t>t_{\alpha / 2 ; f}, H_{0}$ was refused at $\alpha \%$ significance level and alternative hypothesis $H_{1}$ was accepted. Testing of dispersion coincidence was made by means of selected dispersions and was based on Fisher $F$ division. Criteria of testing $F$ were counted as a ratio (Scheer 2007):

$$
F=\frac{s_{1}^{2}}{s_{2}^{2}} .
$$

The higher of two selected dispersions is usually placed as a nominator of testing criteria $F$ for simplification of the end of the test. Therefore it is necessary to consider indices 1 and 2 at the symbol $s$ as formal. The end of the test itself was done on the basis of comparison of values of counted testing criteria $F$ with critical value of $F$ division. Zero hypothesis $H_{0}$ is refused if $F>F_{1-\alpha / 2(f)}$.

\section{Results}

Utilization of social networks is very popular among young people in Slovakia. Facebook has a dominant position among social networks in Slovakia (this research confirmed this fact, too) because it is used regularly by $96 \%$, in absolute expression it means 391 respondents (Fig. 3). It is a suitable product most presented through the media which, in all aspects, suits young people's demands. In-house Azet 
confirmed its popularity among the youth because it is used by more than a half of respondents. In spite of the fact that Google+ has run only for a few months it is used by more than one third of respondents. Even though it is known that Google+ has quite enough users, only a small part of them is really active on this site. It is worth mentioning also the fact that the network LinkedIn, which is oriented occupationally, is used only by a small part $4.2 \%$; it means 17 respondents of our research. It confirms a presumption that this social network is more widely used among professionals than among young people.

Main idea of social network is to connect people, to simplify their communication, to create space for individual and associated presentation and to provide information and sources for relax, entertainment but also occupational intention. Within the research we determined the essential purpose of social networks utilization.

Slovak university students definitely used social networks mostly to maintain contacts with family and friends (Fig. 4). Another significant purpose of social networks utilization is relaxation and entertainment. Many young people have not detected wider possibilities of social networks utilization in the area of personal presentation or finding business contacts and job opportunities so far. Less than $30 \%$ of respondents use social networks markedly or on average for finding job opportunities or personal presentation. We suppose that this type of social networks utilization will increase depending upon age and amount of experience of respondents. It is also possible to suppose growth of users of occupational networks like LinkedIn.

Nowadays there are many ways for looking for career position and the Internet is also very popular. The fact how often Slovak university students used the Internet (except social networks) when looking for career position is presented in Figure 5. Nearly 90\% of respondents used the Internet for job search at least once or it is a way how they look for a job regularly. This fact confirms that the Internet is the dominant medium among young people job search.

Surprisingly we found out that job search via social networks is not so widely used among respondents. It is presented in Figure 6. Only 25\%, in absolute expression it means 100 respondents said that they succeeded in getting a job via social network in the past or they used this way of job search at least once. As many as $72.7 \%$, in absolute expression it means 296 respondents said they did not succeed in job search via social network or they did not use this way of job search. We suppose that this question is related to the purpose of social networks utilization by Slovak university students; dominant reasons are to remain in contact with family and friends combined with relax and entertainment.

In spite of the fact that most respondents did not chance upon the job offer via social network, as many as 54\%, in

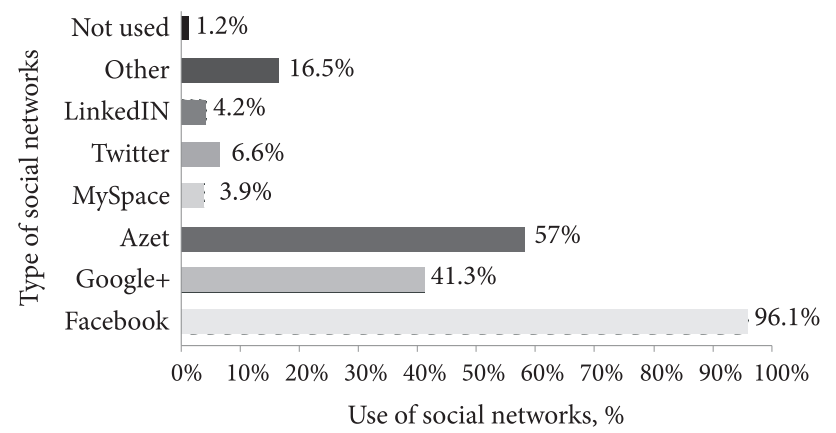

Fig. 3. Most common types of social networks used by Slovak university students

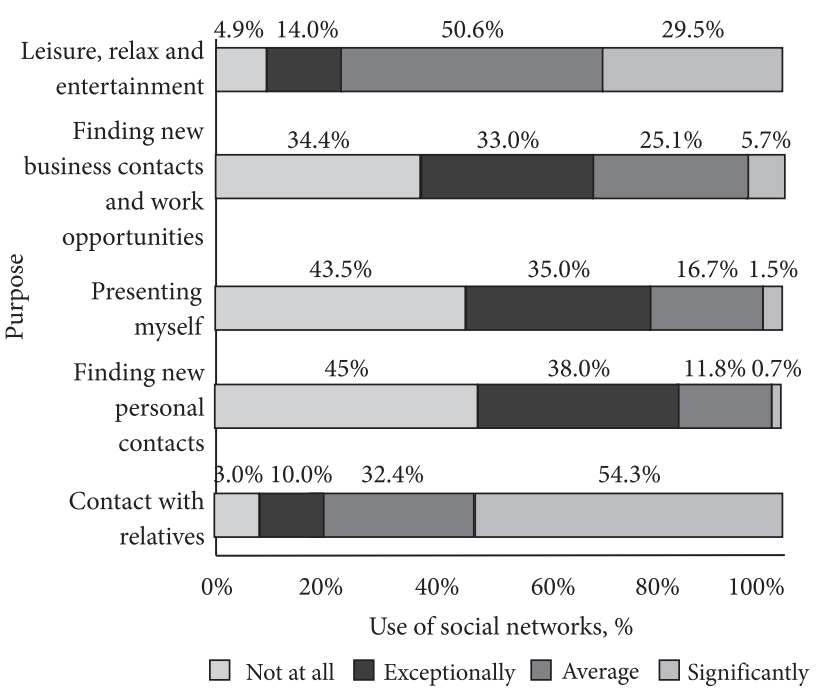

Fig. 4. The purpose of social networks utilization by Slovak university students

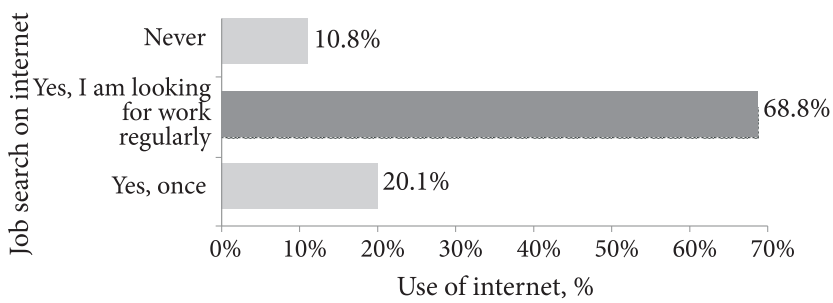

Fig. 5. Job search opportunities via the Internet by Slovak university students

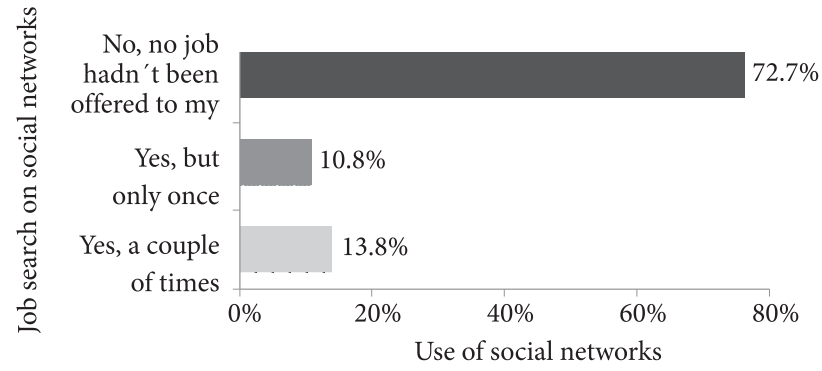

Fig. 6. Job search opportunities via social network by Slovak university students 
absolute expression it means 220 respondents think over social networks as a place where they can find a job, eventually as a place where they can be found by potential employer (Fig. 7). We can state that, from the point of view of young people who were asked within our research, social networks have significant potential to become a place for job search even though most respondents do not have this experience. However, users must be responsible in their own personal presentation and employment service providers must use these possibilities sufficiently.

Interesting finding is that, in spite of previous statements, more than $30 \%$ of respondents do not consider personal presentation on social networks, from the point of view of job search, to be essential (Fig. 8). More than a half of respondents consider possibility of personal presentation

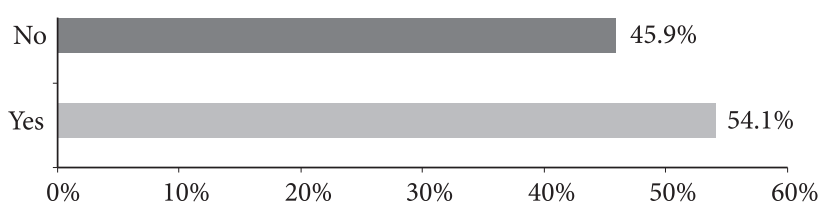

Fig. 7. Do you think of social networks as a place where you can find a job, eventually as a place where you can be found by potential employer?

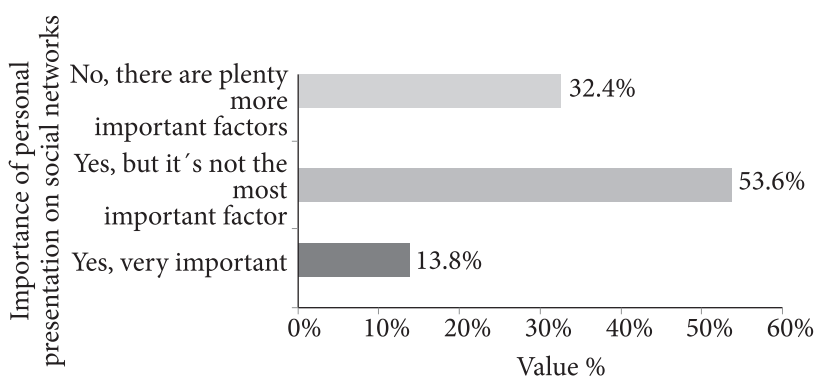

Fig. 8. Is personal presentation on social networks, from the point of view of job search, essential for you? to be essential but in combination with other possibilities, which they consider to be more important. Only 14\% of respondents consider personal presentation on social network to be essential when job search. We suppose these respondents succeeded in getting a job via social network several times in the past.

The purpose of this research was to find out respondents' opinion on the question: What will be more significant when job search in the future (Fig. 9). Most respondents considered classical forms as personal presentation at the interview, analysis of information from occupational $\mathrm{CV}$ and using references, contacts and nepotism to be extremely significant. Many respondents considered personal presentation on social network to be unessential what is in conflict with statements of many famous Slovak personalists.

\section{Conclusions}

According to statements of Zuzana Kaňuchová, a manager of human resources of the most significant Slovak portal profesia.sk, "Slovak employers regard, by choosing future employees, personal profiles on social network, too. Mainly by choosing managers it is substantial to have data and personal contacts not only on the widespread Facebook but also on LinkedIn". "By choosing senior management team companies uses definitely LinkedIn and for positions more oriented in younger people they use social network Facebook". Personnel agency Trenkwalder relies upon this "occupational” networks mainly. Klára Javorská, a specialist for personnel counseling, said in addition to $\mathrm{CV}$ database LinkedIn provides also high quality references for individual candidates. "We also use Facebook but it is not as much usable for looking for appropriate candidates directly (by browsing profiles). It is often used for free job advertising and to achieve supplementary information about candidates who will take part in our interview".

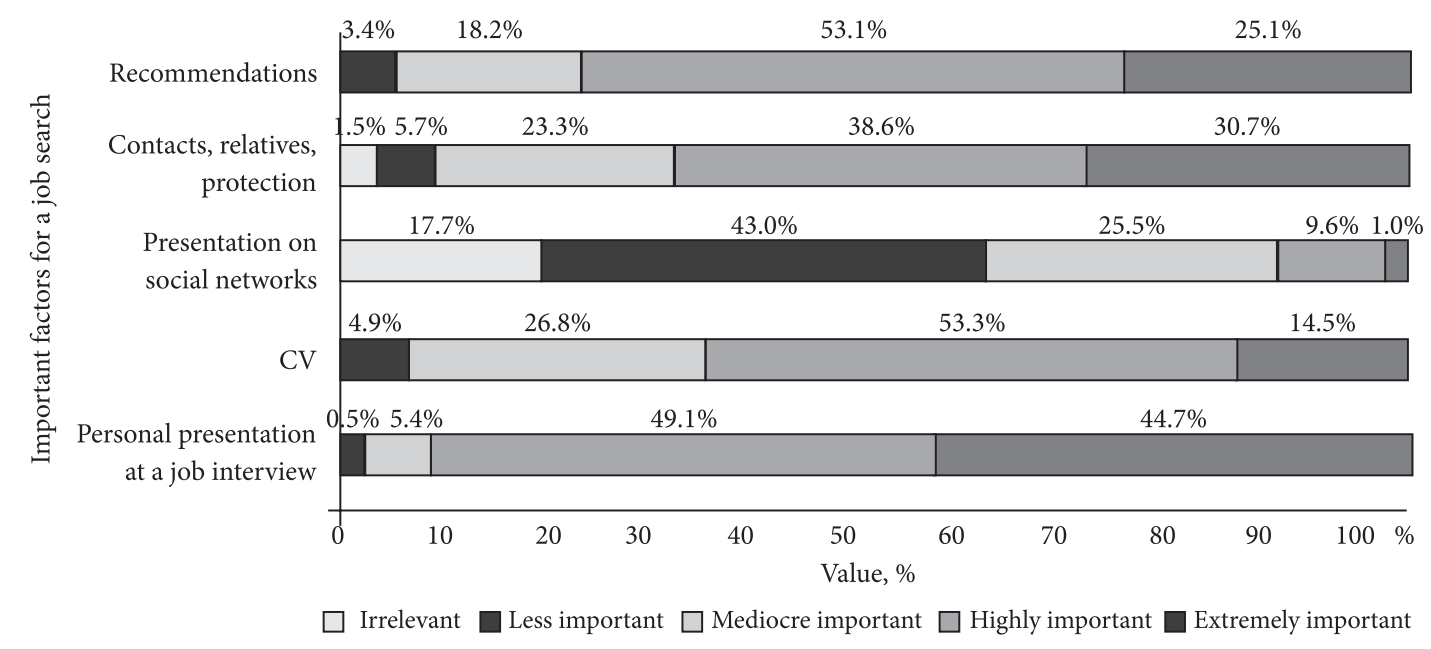

Fig. 9. What, according to your opinion, will have the highest priority for job search in the future? 


\section{The effect of gender difference of candidates on the internet utilization, social networks and on the importance of personal presentation on social networks for job search}

In the interest of explicit confirmation or negation of working hypothesis $H_{1}$ relevant $I$ do not know question from the questionnaire was left open to statistical testing. Null hypothesis $H_{0}$ and in comparison to it alternative hypothesis $H_{1}$ were stated. Testing of null hypothesis was carried out at the significance level $\alpha=0.05$. Testing results are presented in Table 1.

$H_{0:}$ We suppose that arithmetic mean of the Internet utilization frequency (except social networks) in order to look for a job from the point of view of male is equal to arithmetic mean of the Internet utilization frequency in order to look for a job from the point of view offemale and at the same time we suppose that the difference between them, if it exists, is caused by coincident variation of selection results.

$H_{1}$ : We suppose that arithmetic mean of the Internet utilization frequency (except social networks) in order to look for a job from the point of view of male is not equal to arithmetic mean of the Internet utilization frequency in order to look for a job from the point of view of female and at the same time we suppose that the difference between them is not caused by coincident variation of selection results.

Based on results of statistical evaluation of the question we can state that male and female used the Internet in order to look for a job at least once. In case of female the Internet utilization frequency in order to look for a job is higher than in case of male that is also confirmed by the average value of utilization frequency (Table 1). The difference between male and female in the Internet utilization frequency for mentioned purposes we do not consider to be statistically significant considering the achieved significance level ( $\mathrm{p}$-level $=$ 0.876). This difference is caused only because of coincident variation of selection results, i.e. we accept null hypothesis. Following mentioned facts we can accept definitely working hypothesis $H_{1}$ and state that the difference between male and female does not affect the Internet utilization frequency in order to look for a job by Slovak university students.

In the interest of explicit confirmation or negation of working hypothesis $\mathrm{H}_{2}$ we verified, by means of T-test, other null hypothesis at selected significance level $(\alpha=0.05)$. Testing results are presented in Table 2.

$H_{0}$ : We suppose that arithmetic mean of social network utilization frequency by finding new business contacts and job opportunities from the point of view of male is equal to arithmetic mean of social network utilization frequency by mentioned purpose from the point of view offemale and at the same time we assume that the difference between them, if it exists, is caused only by coincident variation of selection results.

$H_{1}$ : We suppose that arithmetic mean of social network utilization frequency by finding new business contacts and job opportunities from the point of view of male is not equal to arithmetic mean of social network utilization frequency by mentioned purpose from the point of view offemale and at the same time we assume that the difference between them, if it exists, is not caused only by coincident variation of selection results.

Based on results of statistical evaluation of the question we can state that male rarely use social network by finding new business contacts and job opportunities and in comparison to female less. In case of female, social network utilization is on average. This difference is not caused only by coincident variation of selection results that is also confirmed by p-level 0.021 . Following mentioned facts we refuse null hypothesis of T-test as well as we refuse working hypothesis $\mathrm{H}_{2}$. We can state definitely that gender difference affects social networks utilization frequency by finding new business contacts and job opportunities by Slovak university students. This discovery is very important for enterprises with free job for female exclusively. Enterprises, in the interest of getting large number of appropriate candidates, should use social networks to advertise their job offer and this way to ensure efficiency of the process of getting employees.

Table 1. T-test the Internet utilization in order to look for a job by male and female

\begin{tabular}{|c|c|c|c|c|c|c|c|c|}
\hline Question & $\begin{array}{c}\text { Mean } \bar{x} \\
\mathrm{M}\end{array}$ & $\begin{array}{c}\text { Mean } \bar{x} \\
\mathrm{~F}\end{array}$ & t-value & p-level & $\begin{array}{c}\text { Std. Dev. } \\
s_{x} \mathrm{M}\end{array}$ & $\begin{array}{c}\text { Std. } \\
\text { Dev. } s_{x} \\
\mathrm{~F}\end{array}$ & $\begin{array}{c}\text { F-ratio } \\
\text { Variance }\end{array}$ & $\begin{array}{c}\mathrm{p} \\
\text { Variance }\end{array}$ \\
\hline $\begin{array}{l}\text { Have you ever used the Internet (except } \\
\text { social networking sites) for job search? }\end{array}$ & 2.57 & 2.59 & -0.171 & 0.864 & 0.71 & 0.67 & 1.144 & 0.364 \\
\hline
\end{tabular}

Table 2. T-test of social networks utilization by searching new business contacts and job opportunities by male and female

\begin{tabular}{|l|c|c|c|c|c|c|c|c|}
\hline \multicolumn{1}{|c|}{ Question } & $\begin{array}{c}\text { Mean } \bar{x} \\
\mathrm{M}\end{array}$ & $\begin{array}{c}\text { Mean } \bar{x} \\
\mathrm{~F}\end{array}$ & t-value & p-level & $\begin{array}{c}\text { Std. Dev. } \\
s_{x} \mathrm{M}\end{array}$ & $\begin{array}{c}\text { Std. Dev. } \\
s_{x} \mathrm{~F}\end{array}$ & $\begin{array}{c}\text { F-ratio } \\
\text { Variances }\end{array}$ & $\begin{array}{c}\mathrm{p} \\
\text { Variance }\end{array}$ \\
\hline $\begin{array}{l}\text { Do I use social networks mainly for } \\
\text { finding new business contacts and } \\
\text { job opportunities? }\end{array}$ & 1.86 & 2.09 & -2.320 & 0.021 & 0.82 & 0.95 & 1.352 & 0.058 \\
\hline
\end{tabular}


Owing to explicit confirmation or negation of working hypothesis $\mathrm{H}_{3}$ two relevant questions from the questionnaire were left open to statistical testing. By means of T-test we verified null hypothesis at selected significance level $(\alpha=$ 0.05). Testing results are presented in Table 3.

$\mathrm{H}_{0}$ : We suppose that arithmetic mean of perceiving of the importance of personal presentation on social networks from the point of view of job search by male (nowadays and in the future) is equal to arithmetic mean of perceiving of the importance of personal presentation on social networks from the point of view offemale and also we assume that the difference between them, if it exists, is caused only by coincident variation of selection results.

$H_{1}$ : We suppose that arithmetic mean of perceiving the importance of personal presentation on social networks from the point of view of job search by male (nowadays and in the future) is not equal to arithmetic mean of perceiving of the importance of personal presentation on social networks from the point of view of female and also we assume that the difference between them, if it exists, is not caused only by coincident variation of selection results.

Resulting from Table 3 we can, based on the average value of perceiving of the importance of personal presentation on social networks, we can state that male and female perceive it, from the point of view of looking for a job nowadays as well as in the future, as important. Female in comparison to male consider personal presentation to be more significant. We do not consider this difference to be statistically significant considering p-level, i.e. we accept null hypothesis of T-test and we confirm working hypothesis $\mathrm{H}_{3}$.

At the same time we can state, following results of T-test and Fisher division, that the gender difference of respondents does not have statistically significant effect on the Internet utilization (except social network) in order to look for a job and the gender difference of respondents does not have statistically significant effect on perceiving of the importance of personal presentation on social networks from the point of view of job search neither now nor in the future by Slovak university students. On the contrary the gender difference has statistically significant effect on social networks utilization frequency by finding new business contacts and job opportunities by Slovak university students.
The Internet and mobile technologies, social media and social networks became a part of everyday life of young people. The Internet became a fundamental tool for successful job search and not only personalists but also job candidates are aware of it. Personalists look for new ways to find future employees via the Internet, whereby they do not use only reliable forms of publishing job offer on specialized portals but they also try to use the potential offered by social networks. The main idea of social networks is to connect people, to simplify their communication, to create space for individual and associated presentation and to provide information and sources for relax, entertainment but occupational intention, too. As the trend of developed world economies shows social networks represent suitable supplement by assessing and choosing candidates for career position. At present many companies (enterprises) in the Slovak Republic still do not use potential of social networks within their utilization for getting, recruiting and assessing potential employees. LinkedIn, Twitter or Facebook are useful tools for finding a job. Profiles on social networks are in the centre of attention of personnel agencies, headhunters or recruiters who actually look for new employees.

Social network Facebook, used in Slovakia much more than other social networks, is used by young people mainly to remain in touch with family and friends and young people spent more time looking for relaxation and entertainment. Most Slovak university students (36\%) spend on social networks on average more than 1 and less than 3 hours a day. Relatively large number of respondents (more than $20 \%)$ spends on social networks more than 3 and less than 6 hours a day. Up to $4 \%$ from respondents polled spend on social networks more than 6 hours a day, what is a relatively high number. Only a few young people have possibility to look for a job via social network even though their opinion is that it will increase significantly in the future. Worldwide well-known occupational social network LinkedIn is not so popular but it is estimated that in Slovakia it is used by approximately 10.000 users. LinkedIn is the social networking site, which is at first sight similar to Facebook, but it is focused on occupational career it allowed users being connected with global job market. From the point of view of job search and getting a job Facebook is assigned for

Table 3. T-test of perceiving of the importance of personal presentation on social networks from the point of view of looking for a job by male and female

\begin{tabular}{|l|c|c|c|c|c|c|c|c|}
\hline \multicolumn{1}{|c|}{ Question } & $\begin{array}{c}\text { Mean } \bar{x} \\
\mathrm{M}\end{array}$ & $\begin{array}{c}\text { Mean } \bar{x} \\
\mathrm{~F}\end{array}$ & $\mathrm{t}$-value & $\mathrm{p}$-level & $\begin{array}{c}\text { Std. Dev. } \\
s_{x} \mathrm{M}\end{array}$ & $\begin{array}{c}\text { Std. Dev. } \\
s_{x} \mathrm{~F}\end{array}$ & $\begin{array}{c}\text { F-ratio } \\
\text { Variances }\end{array}$ & $\begin{array}{c}\mathrm{p} \\
\text { Variances }\end{array}$ \\
\hline $\begin{array}{l}\text { Is personal presentation on social } \\
\text { networking sites from the point of } \\
\text { view job search important for you? }\end{array}$ & 1.74 & 1.84 & -1.482 & 0.139 & 0.58 & 0.68 & 1.362 & 0.051 \\
\hline $\begin{array}{l}\text { Do you emphasise personal } \\
\text { presentation on social networking } \\
\text { sites for job search in the future? }\end{array}$ & 2.24 & 2.37 & -1.294 & 0.196 & 0.84 & 0.94 & 1.250 & 0.157 \\
\hline
\end{tabular}


part-time micro jobs, eventually it serves to look for graduates. However, the service LinkedIn is oriented mainly in working contacts, job search, career or finding personal contacts. Therefore it is suitable for professionals and managers but it can be used when looking for the first job, too.

The effect of social networks on job search of Slovak university students is not significant at the present time but we suppose that trend used in other countries will be asserted in Slovakia gradually.

\section{References}

Bagozzi, R. P.; Lee, K. H. 2002. Multiple routes for social influence: the role of compliance, internalization, and social identity, Social Psychology Quarterly 65(3): 226-247. http://dx.doi.org/10.2307/3090121

Boyd, D. M.-E. 2008. Social network sites: definition, history, and scholarship, Journal of Computer-Mediated Communication 13(1): 210-230. New York: Wiley-Blackwell. ISSN 1083-6101. http://dx.doi.org/10.1111/j.1083-6101.2007.00393.x

Cheung, C. M. K.; Lee, M. K. O. 2010. A theoretical model of intentional social action in onlinesocial networks, Decision Support Systems 49(1): 24-30. http://dx.doi.org/10.1016/j.dss.2009.12.006

Clyde, M. J. 1969. Social networks in urban settings. Manchester: Manchester University Press. 333 p.

Cook, K. S.; Whitmeyer, J. M. 1992. Two approaches to social structure: echange theory and network analysis, Annual Review of Sociology 18: 109-127.

http://dx.doi.org/10.1146/annurev.so.18.080192.000545

Gefen D.; Straub, D. W. 2004. Consumer trust in B2C e-commerce and the importance of social presence: experiments in eproducts and e-services, Omega 32(6): 407-424. http://dx.doi.org/10.1016/j.omega.2004.01.006

Hitka, M., et al. 2013. Zvyšovanie pracovného výkonu zamestnancov: Vedecká monografia. Zvolen: Vyd. TU Zvolen. $179 \mathrm{~s}$. ISBN 978-80-228-2566-5.

Hitka, M.; Balážová, Ž. 2013. The use of corporate culture principles in the position of facility manager. TOYOTARITY - management of intellectual values. Vyd. Alba Iulia Romania. ISBN 978-606-613-078-3.

Hitwise. 2007. Socialnetworking visits increase 11.5 percent from January to February. Retrieved 23 December 2007, from Hitwise.

Ioanides, Y. M.; Loury, L. D. 2004. Job information networks, neighborhood effects, and inequality, Journal of Economic Literature 42(4): 1056-1093. http://dx.doi.org/10.1257/0022051043004595

Jandourek, J. 2007. Sociologický slovník. Praha: Portál. 288 p. ISBN 978-80-7367-269-0.
Jobvite, Inc. 2011. The Jobvite social recruiting survey 2011. Jobvite. ISBN 650-376-7200.

Knoke, D.; Yang, S. 2008. Social network analysis (Quantitative applications in the social sciences). Los Angeles: Sage Publications. ISBN 978-1-4129-2749-9.

Mayer, A. 2012. The structure of social networks and labour market success, Applied Economics Letters 19(13): 1271-1274. ISSN 1350-4851. http://dx.doi.org/10.1080/13504851.2011.619484

Murray, K. E.; Waller, R. 2007. Socialnetworking goes abroad, International Educator 16(3): 56-59.

Ordóñez de Pablos, P. 2002. Knowledge management and organizational learning: typologies of generic knowledge strategies in the Spanish manufacturing industry from 1995 to 1999 , Journal of Knowledge Management 6(1): 52-62. http://dx.doi.org/10.1108/13673270210417691

Rodriguez Pérez, J. M.; Ordóñez de Pablos, P. 2003. Knowledge management and organizational competitiveness: a framework for human capital analysis, Journal of Knowledge Management 7(3): 82-91. http://dx.doi.org/10.1108/13673270310485640

Sanchez-Franco, M. J. 2006. Exploring the influence of gender on the web usage via partial least squares, Behaviour \& Information Technology 25: 19-36. http://dx.doi.org/10.1080/01449290500124536

Scheer, L. 2007. Biometria. Zvolen: Technical University in Zvolen. 333 p. ISBN 978-80-228-1723-3.

Sedláček, M. 2012. Social networks potential in job search, The Journal Social and Economic Revue 3. ISSN 1336-3727.

Short, J. E.; Williams, E. A.; Christie, B. 1976. Theoretical approaches to differences between media, in The Social Psychology of Telecommunications. London, New York: Wiley, 61-76.

Stachová, K.; Stacho, Z. 2010. Employee allocation in Slovak companies, Business: Theory and Practice 11(1):39-48. ISSN 16480627. http://dx.doi.org/10.3846/btp.2013.35

Venkatesh, V.; Morris, M. G. 2000. Why don't men ever stop to ask for directions? Gender, social influence, and their role in technology acceptance and usage behaviour, MIS Quarterly 24: 115-139. http://dx.doi.org/10.2307/3250981

Vetráková, M.; Ďurian, J.; Elexová, G.; Seková, M. 2011. Human resources and their management. EF UMB Banska Bystrica. Zvolen: Bratia Sabovci. 275 p. ISBN 978-80-557-0149-3.

Zhao, J.; Ordóñez de Pablos, P. 2010a. Analysis of cooperative mechanism of industry-academy R\&D alliance lab and case study, Human Factors and Ergonomics in Manufacturing 20(2): 123-134. http://dx.doi.org/10.1002/hfm.20204

Zhao, J.-Y.; Ordóñez de Pablos, P. 2010b. Chinese firms' outward direct investment: technological innovation mechanisms, organizational modes, and improving strategies, Human Factors and Ergonomics in Manufacturing 20(2): 149-160. http://dx.doi.org/10.1002/hfm.20206

Marek POTKÁNY. Doctor of Philosophy, Assoc. Prof. at the Technical University in Zvolen, at the Faculty of Wood Sciences and Technology. Research interests: e-ducation, social networks, analysis of cost, calculation, budgeting, outsourcing and process management.

Alexandra HAJDUKOVÁ. Doctor of Philosophy at the Technical University in Zvolen, at the Faculty of Wood Sciences and Technology. Research interests: human resource management, working conditions, social networks. 